
\title{
3 Research Square \\ Pectinolytic Potential of Differentbacillus Species Isolated From Lepidopteran Insects and Infected Soil
}

Samina Naz Mukry ( $\sim$ smukry@gmail.com )

Department of Microbiology, University of Karachi, Karachi-75270, Pakistan.2Department of Post Graduate Studies \& Research, National Institute of Blood Diseases \& Bone Marrow Transplantation, Karachi-75300, Pakistan.

\section{Sumbul Nazar}

Department of Microbiology, University of Karachi, Pakistan

\section{Muhammad Sohail}

Department of Microbiology, University of Karachi, Pakistan

\section{Shakeel Ahmed Khan}

Department of Microbiology, University of Karachi, Pakistan

\section{Research}

Keywords: Polygalacturonase, thermostable, lepidopteran insects isolates

Posted Date: September 4th, 2020

DOI: https://doi.org/10.21203/rs.3.rs-66250/v1

License: (1) This work is licensed under a Creative Commons Attribution 4.0 International License. Read Full License 


\section{Abstract}

Background: The microorganisms are preferred over plants and animals for the bulk production of industrially important enzymes like pectinases because of their low production-cost, availability of fermentation raw material and the easily controllable production conditions. The pectinolytic potential of a large pool (130) of Bacillus cereus group and non-Bacillus cereus was evaluated. The effect of different physicochemical parameters on polygalacturonase(PGase) production by three promising strains, $\mathrm{B}$. pumilusS76, B.thuringiensis S140(b) and B.taquilensis S140(c) with gene bank accession no. KU981112, KU981113 and KU981114, were studied and the enzyme was partially characterized. The enzyme activity was assayed using dinitrosalicylic acid method.

Results: The polygalacturonases produced by Bp S76, Bt S140(b) and BtqS140(c) were thermostable at temperature above $55^{\circ} \mathrm{C}$ with a melting temperature $(\mathrm{Tm})$ of $72^{\circ} \mathrm{C}, 62^{\circ} \mathrm{C}$ and $57^{\circ} \mathrm{C}$, respectively and the half-life $(\mathrm{T} 1 / 2)$ at $60^{\circ} \mathrm{C}$ of 50,65 and 30 min., respectively. The catabolite repression was noted in presence of glucose while the production increased upon addition of $1 \%$ yeast extract to the growth medium. The enzyme activity was also induced in presence of $\mathrm{Na}+$ and $\mathrm{Ca}+2$.

Conclusion: The strain Bp S76 appeared a better candidate for future biotechnological application owing to the production of higher titers (6.11 IU/L.hrs) of polygalacturonase with greater stability.

\section{Full Text}

This preprint is available for download as a PDF.

\section{Figures}

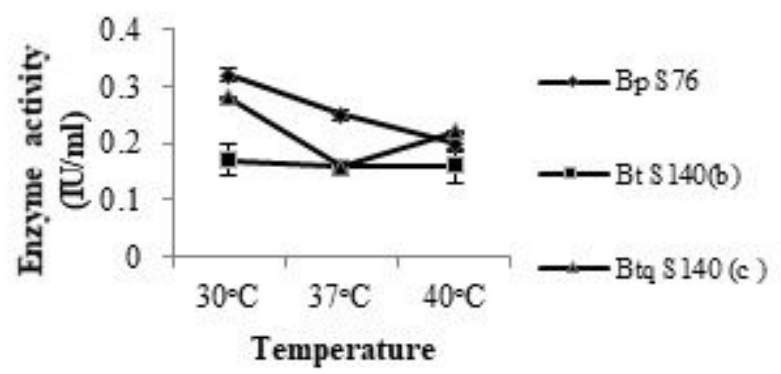

Figure 1

Influence of growth temperature on polygalacturonase production 


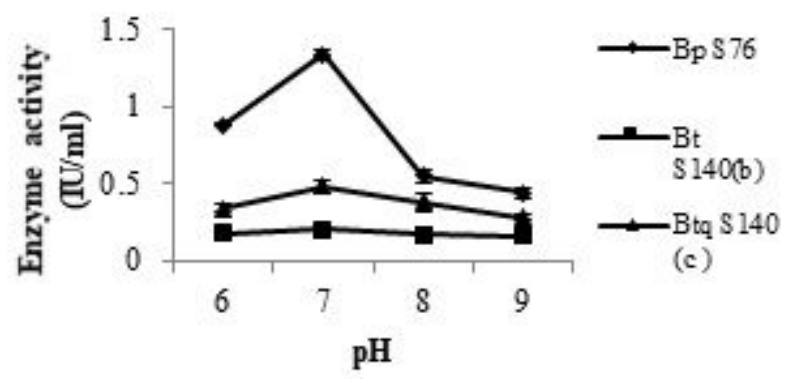

Figure 2

Effect of $\mathrm{pH}$ on polygalacturonase production.

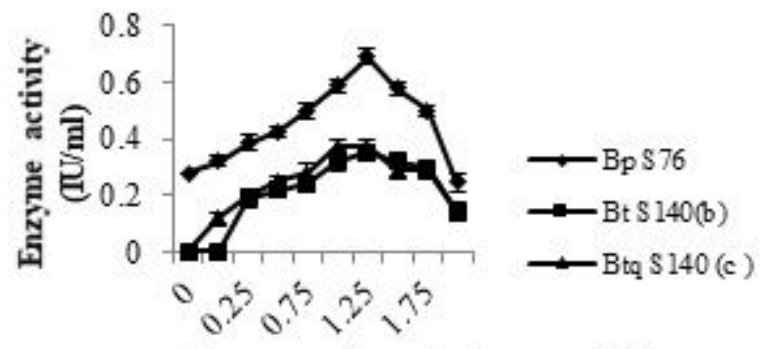

Concentration of substrate (\%)

\section{Figure 3}

Influence of varying concentration of substrate on polygalacturonase production.

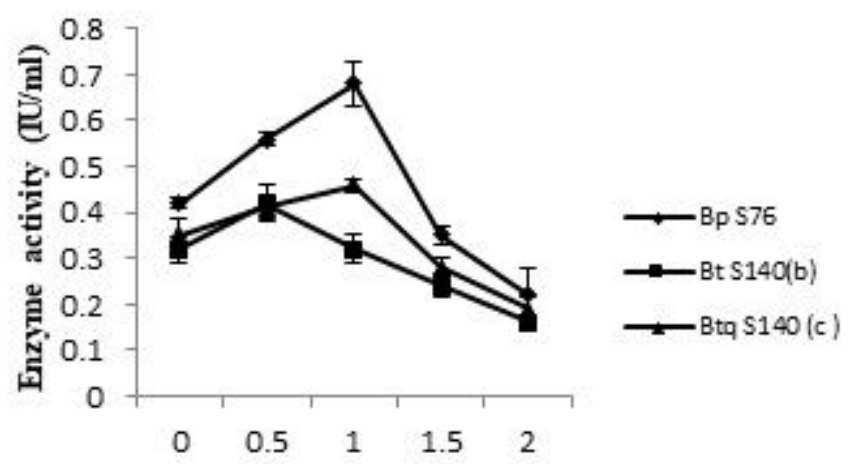

Concentration of nitrogen ( $\%)$

\section{Figure 4}

Effect of nitrogen-concentration on polygalacturonase production. 


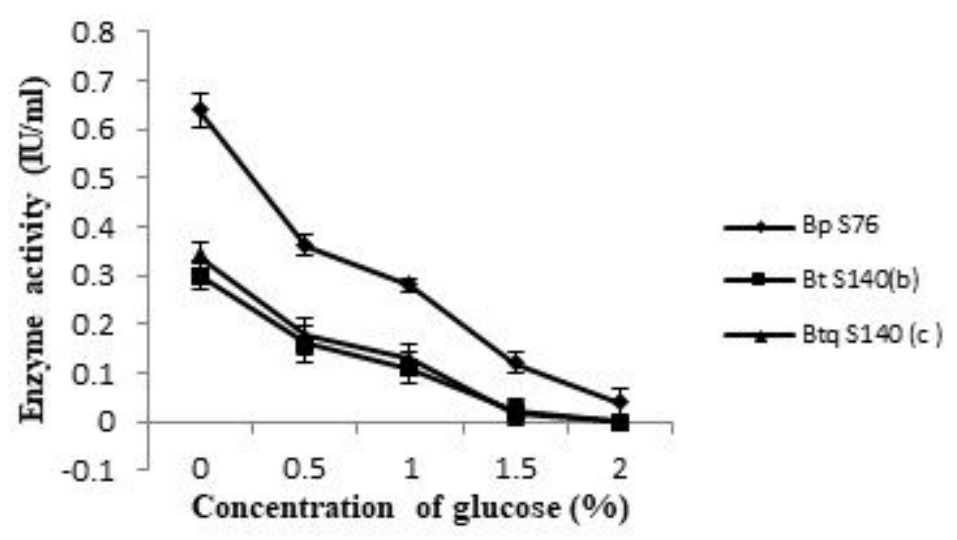

Figure 5

Effect of glucose concentration on polygalacturonase production.

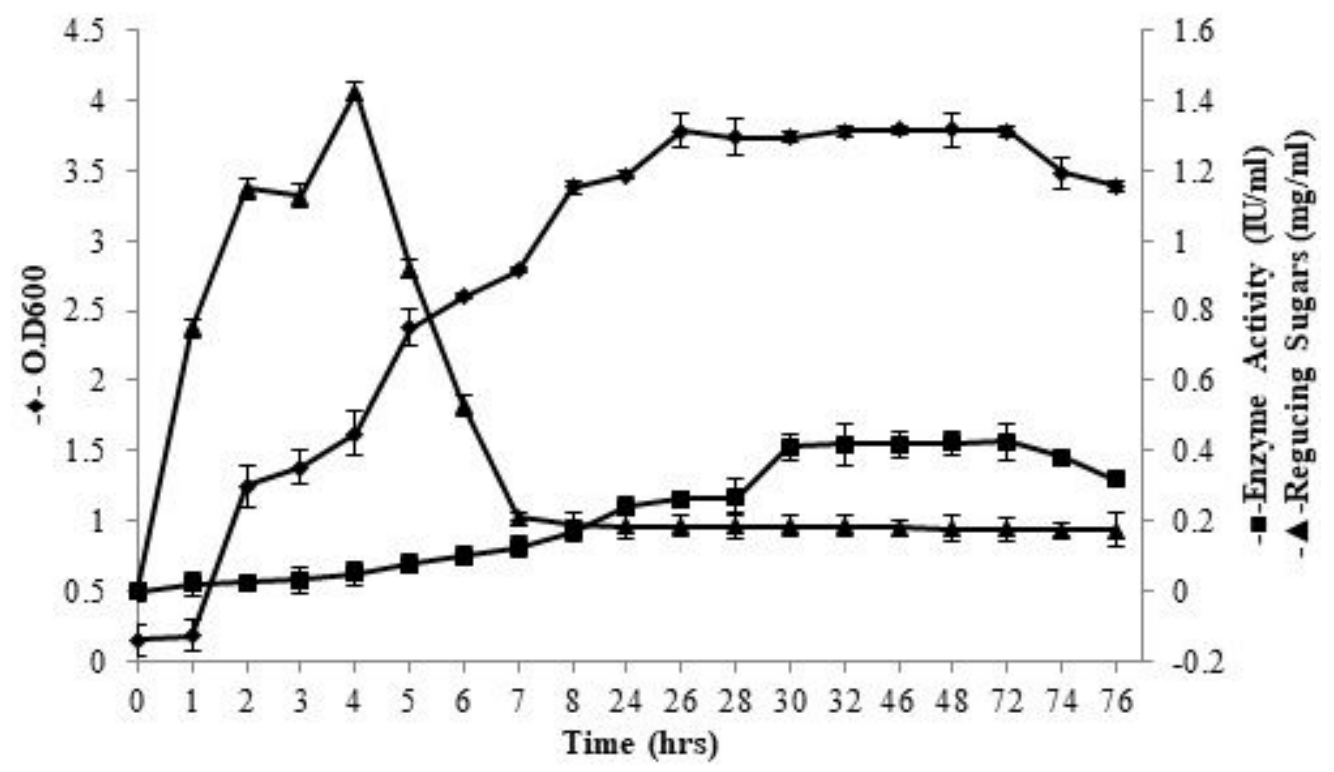

Figure 6

Comparison of growth, polygalacturonase production kinetics and amount of reducing sugarsproduction by BpKU-S-76. ( $\mathrm{g}=$ generation time; $\mathrm{Qp}=$ volumetric productivity of enzyme)

\section{Supplementary Files}

This is a list of supplementary files associated with this preprint. Click to download.

- Tables.docx

- Graphicalabstract.docx 